\section{Early Reactivation of European Rivers During the Last Deglaciation}

\author{
Guillemette Ménot, ${ }^{1 *}$ Edouard Bard, ${ }^{1 *}$ Frauke Rostek, ${ }^{1}$ Johan W. H. Weijers, ${ }^{2}$ \\ Ellen C. Hopmans, ${ }^{2}$ Stefan Schouten, ${ }^{2}$ Jaap S. Sinninghe Damsté ${ }^{2}$
}

During the Last Glacial Maximum, the sea-level lowstand combined with the large extent of the Fennoscandian and British ice sheets led to the funneling of European continental runoff, resulting in the largest river system that ever drained the European continent. Here, we show an abrupt and early reactivation of the European hydrological cycle at the onset of the last deglaciation, leading to intense discharge of the Channel River into the Bay of Biscay. This freshwater influx, probably combined with inputs from proglacial or ice-dammed lakes, dramatically affected the hydrology of the region, both on land and in the ocean.

$\mathrm{D}$ espite the recognized sensitivity of oceanic circulation to changes in the freshwater budget at high latitudes (1-4), river runoff studies have so far mainly been focused on low-latitude paleorecords (5-7). Furthermore, except for a few continental archives such as speleothems and wetlands that reflect local conditions, little is known about hydrological and water drainage changes in Europe during the last deglaciation. During the Last Glacial Maximum (LGM), a large ice sheet (known as the Fennoscandian ice sheet) was established on the Eurasian continent. Both the sea-level lowstand and the extent of the ice sheet deeply influenced the drainage basins of European rivers that flowed into the Channel River, thus generating one of the largest rivers ever to have extended across the European continent (Fig. 1). Because this river transported much of the meltwaters coming from the European glaciers as well as from the Fennoscandian and British-Irish ice sheets $(8,9)$, its runoff is expected to have reacted strongly to the retreat and growth of the Eurasian ice-sheets and of the alpine glaciers. Therefore, a record of the activity of this paleoriver could provide a detailed account of the effect of European deglaciation on the hydrological cycle.

Core MD952002 $\left(47^{\circ} 27^{\prime} \mathrm{N}, 8^{\circ} 32^{\prime} \mathrm{W}, 2174-\mathrm{m}\right.$ water depth) was recovered on the northwestern slope of the Bay of Biscay in the direct axis of the English Channel during the IMAGES 101 cruise of the research vessel Marion Dufresne (Fig. 1). The chronology of this core is based on calibrated ${ }^{14} \mathrm{C}$ ages $(10)$. This core covers a critical period including the last deglaciation, as well as abrupt climatic

${ }^{1}$ CEREGE, Collège de France, UMR 6635, CNRS Université Aix-Marseille III, Europole de l'Arbois, BP 80, 13545 Aix-enProvence, France. ${ }^{2}$ Department of Marine Biogeochemistry and Toxicology, Royal Netherlands Institute for Sea Research (NIOZ), Post Office Box 59, 1790 AB Den Burg, Texel, Netherlands.

${ }^{*}$ To whom correspondence should be addressed. E-mail: gmenot@cerege.fr (G.M.); bard@cerege.fr (E.B.) Channel River outlet. changes such as Heinrich events 1 and 2 (H1 and $\mathrm{H} 2$ ), which are clearly identified by two discrete peaks in the abundance of lithic grains and the magnetic susceptibility at 16 and 24 thousand years before the present (kyr B.P.) (Fig. 2B) (11). Total organic carbon (TOC) content varies between 0.2 and $1.2 \%$, with minima during both $\mathrm{H} 1$ and $\mathrm{H} 2$ events (green circles in Fig. 2C). The $\mathrm{C}_{37: 4}$ alkenone, a biomarker derived from haptophyte algae and thought to be a proxy for low-salinity water associated with icebergs (12), is absent during the Holocene but exhibits high values between 11 and 18 kyr B.P., with a prominent maximum reached during $\mathrm{H} 1$, corresponding to $30 \% \mathrm{C}_{37: 4}$ among the total of $\mathrm{C}_{37}$ alkenones (black diamonds in Fig. 2C). This is a characteristic feature for $\mathrm{H} 1$ in this area and has been related to the advection of low-salinity water associated with icebergs (12).

We applied the branched and isoprenoid tetraether (BIT) index to reconstruct terrestrial organic matter fluvially transported to the ocean (13). This proxy uses the relative abundance

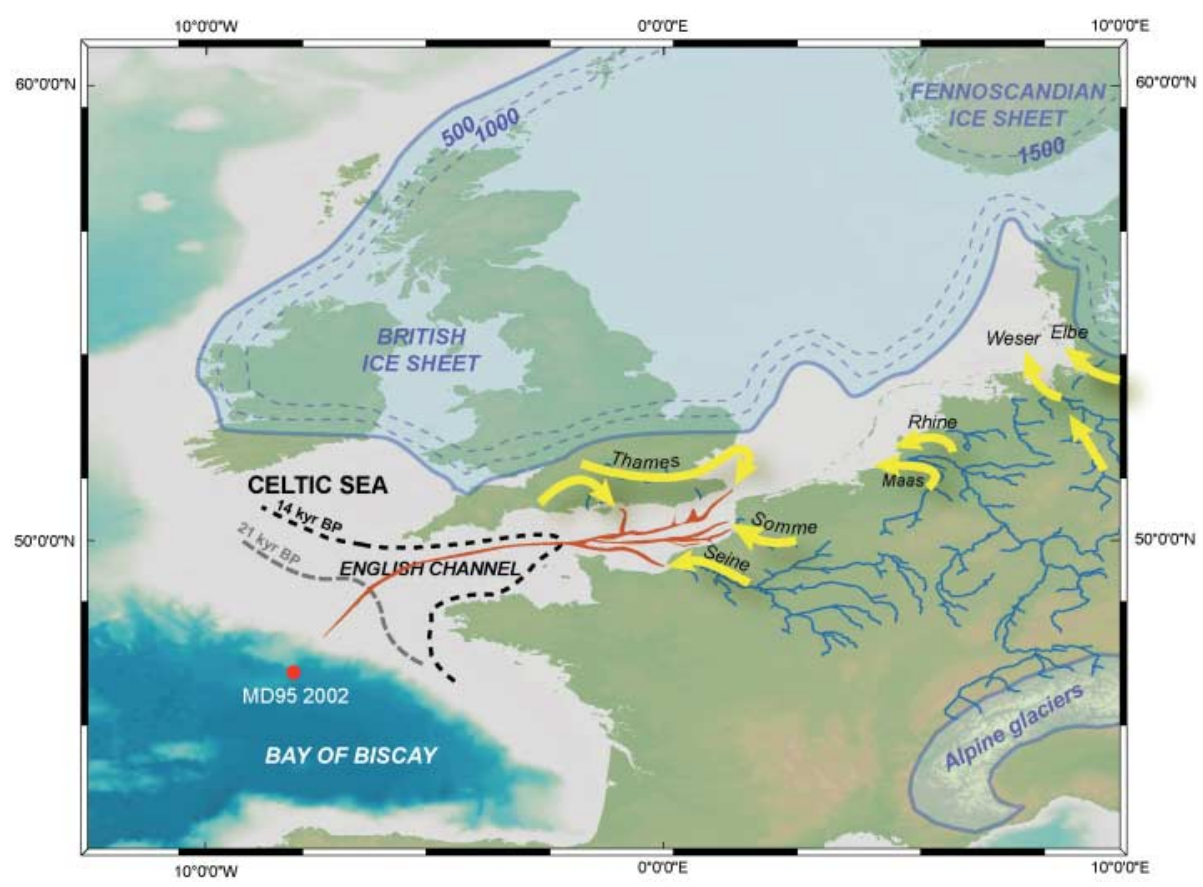

Fig. 1. The paleoenvironment of the LGM on the Eurasian continent was radically different from today. The Fennoscandian ice sheet was established on the northern part of Europe, extending west into the Norwegian Sea, south across the north German Plain into Poland, and eastward into North Poland and Russia $(27,28)$. A smaller dome was installed on the British Isles (27). Recent geomorphological evidence indicates that the British-Irish ice sheet (BIS) and Fennoscandian ice sheet coalesced, and a huge ice dam extended over the present-day North Sea $(28,35)$. The Alps were almost entirely covered by an ice dome formed by valley glaciers (36). The maximum extent of ice sheets at the LGM is illustrated by the blue contours. A final ice-age sea-level lowstand led to emersion of the channel between England and France, with the coastlines at 14 and 21 kyr B.P. illustrated by the dashed lines (after 31). A paleo-river, known as the Channel River (in orange), extended across the emerged continental margin (37). It drained most of the major rivers in northwestern Europe, that is, the Rhine, Maas, Seine, Solent, and Thames (yellow arrows on the map). In addition to these rivers, the Irish Sea drained a large part of the BIS meltwaters (32). Furthermore, damming by the Fennoscandian ice sheet favored the development of southward-flowing meltwater valleys and ice-margin spillways running westward. These spillways collected proglacial waters from rivers even farther east than the Elbe basin and allowed drainage to the Channel River $(26,28)$. Core MD952002 (red dot) was taken at a water depth of $2174 \mathrm{~m}$ in the axis of the English Channel, close to the LGM position of the 
of membrane lipids (i.e., nonisoprenoid glycerol dialkyl glycerol tetraethers) (14) derived from anaerobic bacteria thriving in soils and peats (15), compared with crenarchaeol, a structurally related isoprenoid molecule characteristic of ubiquitous marine

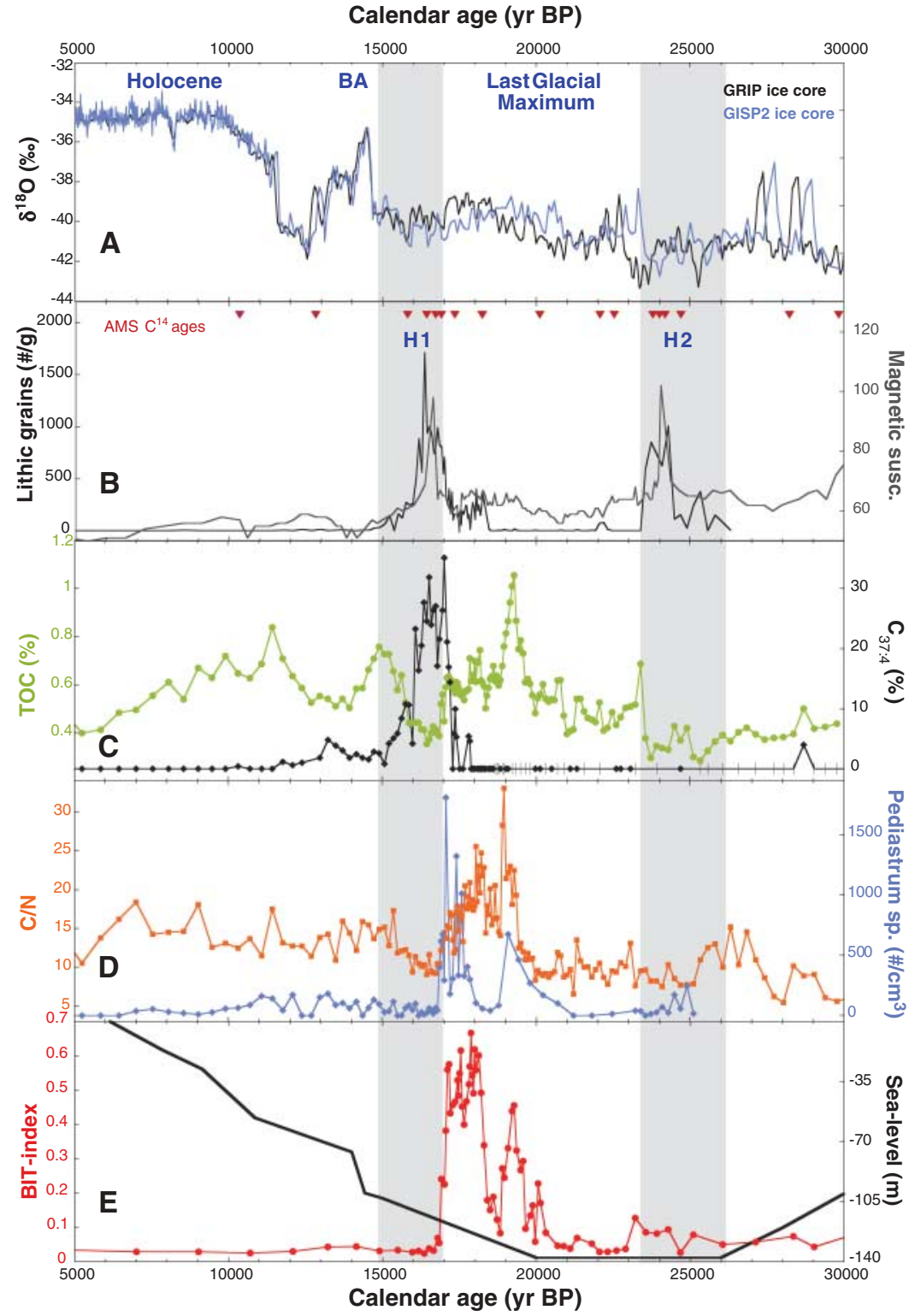

Fig. 2. Deglaciation-Holocene records of the past activity of the Channel River as a function of paleoclimatic changes. The chronology is based on calibrated ${ }^{14} \mathrm{C}$ ages measured on planktonic foraminifera [shown as triangles in (B)] (10). Climatic events are abbreviated as follows: B-A, Bølling-Allerød; $\mathrm{H} 1$, Heinrich 1 ; and $\mathrm{H} 2$, Heinrich 2. The gray areas underline the $\mathrm{H} 1$ and $\mathrm{H} 2$ events. (A) $\delta^{18} 0$ GRIP (black line) (38) and $\delta^{18} 0$ GISP2 (light blue line) (39) records reflecting Greenland air temperatures. (B) Black line shows the counting of grains identified as ice-rafted debris (IRD) per $10 \mathrm{~g}$ for the size fraction coarser than $150 \mu \mathrm{m}$, and the gray curve shows the magnetic susceptibility (MS) record measured on board Marion Dufresne (40). (C) Green circles represent the total organic carbon contents, and the black diamonds the percentage of $C_{37: 4}$ among $C_{37}$ alkenones, i.e., $\% C_{37: 4}=100 \times\left[C_{37: 4}\right] /\left[C_{37: 2}+C_{37: 3}+C_{37: 4}\right]$. Beyond $19 \mathrm{kyr}$ B.P., the relative percentage of $C_{37: 4}$ could not be quantified because alkenones are very scarce in the sediments corresponding to the last glacial period (black ticks in Fig. $2 \mathrm{C}$ and italics in table S1). (D) Orange squares indicate the total organic carbon-to-nitrogen ratios (C/N), and the blue symbols show the abundance of freshwater algae, Pediastrum sp. [counts from (11)]. (E) The BIT index, which is defined as follows: BIT $=(\mathrm{I}+\mathrm{II}+\mathrm{III}) /[(\mathrm{I}+\mathrm{II}+\mathrm{III})+(\mathrm{IV})]$ [the roman numbers refer to the glycerol dialkyl glycerol tetraethers in figure 1 of (13)], and is represented here by red dots. The black curve shows the sea-level curve (41). Analytical data for core MD952002 are given in table S1. planktonic and lacustrine crenarchaeota (16). BIT values for suspended particulate matter in river waters are typically $>0.9$ (17). A survey of Holocene sediments showed that the BIT index can be directly correlated to the relative amount of fluvial terrestrial organic matter input. BIT-index values of $<0.1$ are typical for open marine settings receiving only small amounts of terrestrial organic matter, whereas values $>0.4$ are typical for river fans and fjord systems (13). The BITindex values throughout the core MD952002 remain below 0.1 , except for two well-defined peaks with values as high as 0.7 centered at $19.5 \mathrm{kyr}$ B.P. and between 19 and $17 \mathrm{kyr}$ B.P. (red circles in Fig. 2E). The two maxima in the BIT-index profile, therefore, reveal periods during which large amounts of terrestrial organic matter must have been transported to this site in the Bay of Biscay. These maxima are consistent with those obtained from the abundance of remains of freshwater algae (Pediastrum sp.) (blue curve on Fig. 2D) (11). The total organic carbon-to-nitrogen ratio $(\mathrm{C} / \mathrm{N})$ varies between 5 and 30 , with minimum values typical of the marine environment end-member during $\mathrm{H} 1$ and $\mathrm{H} 2$ events, and higher values in the intervening period, also indicative of a larger terrestrial contribution (Fig. 2C).

During $\mathrm{H} 2$ and the LGM, cold and dry conditions prevailed on the European continent (18). At that time, ice sheets reached their maximum extent (Fig. 1), and sedimentation at the Channel River outlet was typical of a marine environment with low values of the BIT index and TOC as well as low $\mathrm{C} / \mathrm{N}$ ratios (Fig. 2, C to E). At the end of the LGM, between 21 and 17 kyr B.P., an early warming is observed in the Greenland air-temperature record (Fig. 2A). This temperature increase is also clearly detected in several North Atlantic records (e.g., 12, 19-21) as well as in continental reconstructions inferred from pollen in lacustrine and peat sequences over Europe (e.g., 22, 23). This warming was accompanied by enhanced precipitation, as is also evident from the pollen assemblages. Despite this climatic warming, soils remained partly frozen and hence impermeable (24). Furthermore, the vegetation cover was scarce and spatially discontinuous, mainly composed of peat with only few woody species (25). This situation led to the development of large fluvial systems, intense soil erosion, and enhanced river discharge. This transient period is coincident with an abrupt maximum in the BIT index in core MD952002 (Fig. 2), indicative of an early and drastic reactivation of European rivers.

Associated with this reactivation of the hydrological cycle, meltwaters might well have played a role in the runoff increase. In fact, when the Fennoscandian ice sheet started to retreat from its maximum position 
at $\sim 22$ kyr B.P., a new series of short-lived glacial lakes formed at its southern margin, more particularly in the Polish basins and German lowlands $(26,27)$. Because of the position of the ice margin, the meltwaters first drained through the southern Peribaltic area toward central Poland, to the Elbe River, and then to the Channel River (28). The retreat was not continuous, and readvances of the Fennoscandian ice sheet have been recognized based on geomorphological and lithostratigraphic evidences as well as by cosmonuclide and thermoluminescence dating $(26,27)$. Two major deglaciation phases have been reported in Poland during the low sea-level stand: the Poznan and the Pomeranian phases at 22.0 and $18.6 \mathrm{kyr}$ B.P., respectively (26). Similar pulsations have been described for the British-Irish ice sheet over the same period (27). On the southeastern sector, the Scandinavian ice sheet begins to retreat around 19 kyr B.P. after a phase of maximum extent at $20.9 \mathrm{kyr}$ B.P. (29). A massive and early breakdown of the LGM system of ice domes in the Alps is reported to occur simultaneously (e.g., 30).

A peculiar geographic setting reinforced the effect of this increased water runoff from the European continent, leading to increased discharge of the River Channel into the Bay of Biscay. In fact, the low sea level during the LGM (Fig. 2E) means that the river mouth was located very close to the core location [the dashed line in Fig. 1 represents the paleocoastline at 21 kyr B.P., reconstructed after (31)]. Moreover, due to the topography of the catchment basin, the Channel River drained a large area with inputs from the Rhine, Seine, Maas, and Thames basins (9). This topographic funneling effect was reinforced by the location of the British-Irish ice sheet, which reached its maximum extent at 16.7 kyr B.P. (32). A simultaneous readvance of the Scandinavian ice sheet is recorded on the southeastern sector (29).

The onset of the $\mathrm{H} 1$ event, at 17 kyr B.P., is characterized by the sudden drop in the BIT index (Fig. 2E). As already observed for Heinrich events (19), the biological productivity is low, but the BIT index indicates a predominant marine origin for the sedimentary organic matter (Fig. 2). Consistently, the $\mathrm{C} / \mathrm{N}$ record exhibits a clear minimum over this time interval. Furthermore, a prominent $\mathrm{C}_{37: 4^{-}}$ alkenone peak is synchronous with the maximum abundance in lithic grains. A similar maximum of $\mathrm{C}_{37: 4}$ linked to $\mathrm{H} 1$ has already been described at other sites $(33,12)$. The fall in BIT index is clearly simultaneous with the rise in lithic grain abundance and percentage of $\mathrm{C}_{37: 4}$ alkenone, indicating that this switch was probably due to the impact on marine hydrology of icebergs coming from the Fennoscandian and Laurentide ice sheets
(34). In parallel, the return to dry and cold conditions on the continent during H1 probably led to a regime with less fluvial runoff.

There was no recurrence of high BIT-index values when warmer and wetter conditions returned during the Bølling-Allerød and the Holocene period (Fig. 2E). This is probably due to the sea-level rise of about $60 \mathrm{~m}$ compared with the LGM lowstand, which caused a northward displacement of the river mouth by about $300 \mathrm{~km}$ and thus a more attenuated influence of the Channel River at the core site (Fig. 1). Furthermore, due to the position of the Fennoscandian ice margins during the BøllingAllerød, the meltwaters of the Peribaltic area drained into the southern part of the Baltic Basin and no longer through Poland and the Elbe Basin (28).

The abrupt runoff event that occurred at the onset of the last deglaciation on the European continent is unique in magnitude and timing and reflects an early reactivation of the European hydrological cycle leading to an intense discharge of terrestrial organic matter on the Celtic Margin and Bay of Biscay. The intensity of this event is due to a peculiar combination of topographic and paleoclimatic factors: The large extent of the Fennoscandian and British ice sheets, which coalesced over the North Sea, forced the drainage of rivers into the Channel River, thus creating one of the largest river systems ever existing on the European continent. The reactivation of European river runoff has also probably been fuelled by proglacial lakes developing at the southern margin of the ice sheets. Indeed, high abundances of remains of freshwater algae are found simultaneous with the large increase in BIT index (Fig. 2). Interestingly, although the freshening of the surface waters starting at $21.5 \mathrm{kyr}$ B.P. is progressive and parallel to the temperature increase after the LGM, the return to fully marine conditions is sharp and occurs in about a century at the start of the H1 event. As a result of sea-level rise, after 17 kyr B.P., conditions never became suitable again for recording events of the Channel River of such a magnitude in the Bay of Biscay.

Our results reveal large changes in the magnitude of the discharge of cold freshwater into the North Atlantic during the last deglaciation. This situation is similar to that reconstructed for the Laurentide ice sheet, meltwater outflow which probably affected the meridional overturning circulation $(1,3)$. Modeling experiments could help to evaluate the effect of the European river reactivation on the millennium-scale climatic events that punctuated the last deglaciation.

\section{References and Notes}

1. W. S. Broecker et al., Nature 341, 318 (1989).

2. T. F. Stocker, D. G. Wright, Nature 351, 729 (1991).

3. S. Manabe, R. J. Stouffer, Paleoceanography 12, 321 (1997).

4. A. Ganopolski, S. Rahmstorf, Nature 409, 153 (2001).
5. A. T. Adegbie, R. R. Schneider, U. Rohl, G. Wefer, Palaeogeogr. Palaeoclimatol. Palaeoecol. 197, 323 (2003)

6. T. C. Jennerjahn et al., Science 306, 2236 (2004).

7. E. Schefuß, S. Schouten, R. R. Schneider, Nature 437, 1003 (2005).

8. J. D. Scourse, I. R. Hall, I. N. McCave, ]. R. Young, C. Sugdon, Earth Planet. Sci. Lett. 182, 187 (2000).

9. P. Antoine et al., J. Quat. Sci. 18, 227 (2003).

10. Methods are available as supporting material on Science Online.

11. S. Zaragosi et al., Earth Planet. Sci. Lett. 188, 493 (2001).

12. E. Bard, F. Rostek, J.-L. Turon, S. Gendreau, Science 289, 1321 (2000).

13. E. C. Hopmans et al., Earth Planet. Sci. Lett. 224, 107 (2004)

14. J. S. Sinninghe Damsté, E. C. Hopmans, R. Pancost, S. Schouten, J. A. ]. Geenevasen, J. Chem. Soc. Chem. Commun. 2000, 1683 (2000).

15. J. W. H. Weijers et al., Environ. Microbiol. 8, 648 (2006).

16. J. S. Sinninghe Damsté, E. C. Hopmans, S. Schouten, A. C. T. van Duin, J. A. J. Geenevasen, J. Lipid Res. 43, 1641 (2002)

17. L. Herfort et al., Limnol. Oceanogr. 51, 2196 (2006).

18. J. R. Allen et al., Nature 400, 740 (1999).

19. D. Pailler, E. Bard, Palaeogeogr. Palaeoclimatol. Palaeoecol. 181, 431 (2002).

20. G. A. Jones, L. D. Keigwin, Nature 336, 56 (1988).

21. R. B. Alley, E. J. Brook, S. Anandakrishnanc, Quat. Sci. Rev. 21, 431 (2002)

22. M. F. Sanchez Goñi, ]. L. Turon, F. Eynaud, S. Gendreau, Quat. Res. 54, 394 (2000).

23. ]. L. Combourieu Nebout et al., Geology 30, 863 (2002)

24. H. Renssen, ]. Vandenberghe, Quat. Sci. Rev. 22, 209 (2003).

25. P. C. Tzedakis, I. T. Lawson, M. R. Frogley, G. M. Hewitt, R. C. Preece, Science 297, 2044 (2002).

26. L. Marks, Quat. Sci. Rev. 21, 103 (2002)

27. D. Q. Bowen, F. M. Phillips, A. M. McCabe, P. C. Knutz, G. A. Sykes, Quat. Sci. Rev. 21, 89 (2002).

28. J. Mangerud et al., Quat. Sci. Rev. 23, 1313 (2004)

29. V. R. Rinterknecht et al., Science 311, 1449 (2006).

30. S. Ivy-Ochs, H. Kerschner, P. W. Kubik, Ch. Schlüchter, J. Quat. Sci 21, 115 (2006).

31. K. Lambeck, Palaeogeogr. Palaeoclimatol. Palaeoecol. 129, 1 (1997).

32. A. M. McCabe, P. U. Clark, Nature 392, 373 (1998).

33. A. Rosell-Melé, Paleoceanography 13, 694 (1998).

34. F. E. Grousset, C. Pujol, L. Labeyrie, G. Auffret, A. Boelaert, Geology 28, 123 (2000).

35. J. Svendsen et al., Quat. Sci. Rev. 23, 1229 (2004).

36. G. H. Denton, T. ]. Hughes, Eds., The Last Great Ice Sheets (Wiley, New York, 1981).

37. ].-F. Bourillet, ].-Y. Reynaud, A. Baltzer, S. Zaragosi, J. Quat. Sci. 18, 261 (2003)

38. S. J. Johnsen et al., J. Quat. Sci. 16, 299 (2001).

39. M. Stuiver, P. M. Grootes, Quat. Res. 53, 277 (2000).

40. G. Auffret et al., Mar. Geol. 188, 79 (2002).

41. K. Lambeck, Y. Yokoyama, T. Purcell, Quat. Sci. Rev. 21, 343 (2002)

42. We thank S. Zaragosi and F. Eynaud for useful discussions. Paleoclimate work at CEREGE is supported by grants to E.B. from the CNRS, the ANR, the Gary Comer Science and Education Foundation, and the European Community (project STOPFEN, HPRN-CT-2002-0221). The work at NIOZ was supported by grants to E.C.H. and J.S.S.D. from the Netherlands Organisation for Scientific Research (NWO).

Supporting Online Material

www.sciencemag.org/cgi/content/full/313/5793/1623/DC1 Methods

Table S1

26 May 2006; accepted 28 July 2006

$10.1126 /$ science. 1130511 